\title{
Redress at a higher education institution: Art processes as embodied learning
}

\author{
Elmarie Costandius, Amelda Brand, and Gera de Villiers \\ Stellenbosch University \\ Corresponding Author: elmarie@sun.ac.za
}

(Submitted: 3 May 2020; Accepted: 13 August 2020)

\begin{abstract}
In January 2019, a visual redress project was launched at Stellenbosch University, South Africa that introduced new artworks and contextualised existing statues around campus. However, it became clear that this dual installation and contextualisation did not sufficiently provide a means to address structural, systemic racial injustices inherent in the colonial and apartheid past; a more embodied way of engagement was needed. Therefore, workshops combining art and performance were introduced where lecturers, students and community members worked through social, political, and personal issues. This entanglement of art, performance, bodies, and space became a method that changed and evolved with each workshop. It was a dynamic, fluid, and relational process that could not be prescriptive as it depended on the elements constituting it. In this article, the various workshops are discussed, and it is shown how new topics and affective reactions at each workshop emerged through the art processes and practices.
\end{abstract}

Keywords: art process, embodied learning, redress, transformation

\section{Introduction}

There is a need for redress in South Africa - for an embracing of justice, responsibility, and equality. The transition from apartheid to democracy was about liberating a majority who were denied basic political and socio-economic rights (Bentley and Habib, 2008). Redress has been underway in South Africa for more than two decades; however, it has been a slow and unequal process, which has resulted in a few elite experiencing the benefits of redress, while the poor remain in a similar or worse position. The socio-economic policies and practices of the past decades should be revalued, and the promotion of more practical, equal, and long-lasting redress projects should be considered. Redress in higher education institutions is a small but very necessary part of these projects.

The \#RhodesMustFall movement started in March 2015 at the University of Cape Town and campaigned for the removal of the statue of Cecil John Rhodes. It later led to a wider student movement called \#FeesMustFall, which focused on the decolonisation of education at higher 
education institutions in South Africa. Decolonisation is the process of undoing colonialism, but even though colonialism could be seen as something of the past, it still has an effect in the present, hence the need for more appropriate actions, framed as decoloniality. Decoloniality is a 'critique of coloniality, it resists expressions of coloniality, and takes actions to overcome coloniality' (Le Grange, 2018: 9). There is an urgent need for recognition and legitimacy of histories and knowledge that have been misrecognised and marginalised.

At Stellenbosch University (SU) ${ }^{1}$ a process was started to address the visual environment of the campus. The visual aspects of the SU campus specifically became prominent with the \#FeesMustFall protests, when students expressed their feelings of exclusion and misrepresentation regarding statues on campus. This resulted in a Visual Redress project driven by the Department of Visual Arts and the Transformation Office, in which some of the artists who participated in the protests came up with ideas for alternative sculptures, such as the eleven women in a circle (Figure 1) and benches with welcoming messages (Figure 2) in all twelve official languages as well as San, Kaaps, Muslim Kaaps, and Braile on the Rooiplein, the main square on the main campus.

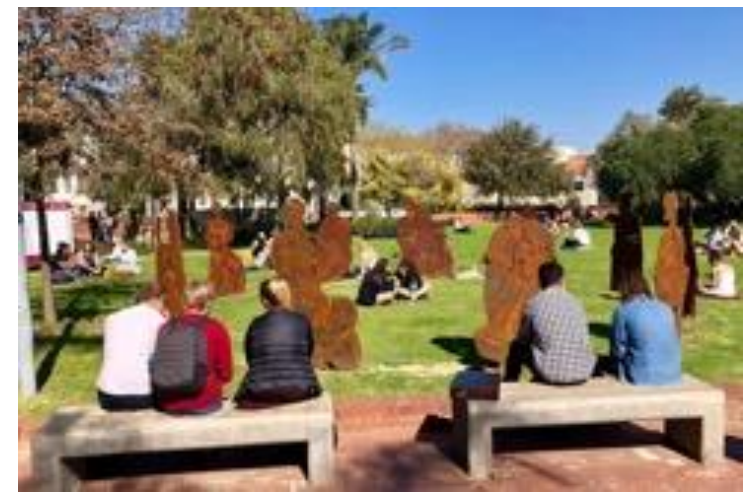

Figure 1: Sculpture of eleven women in a circle

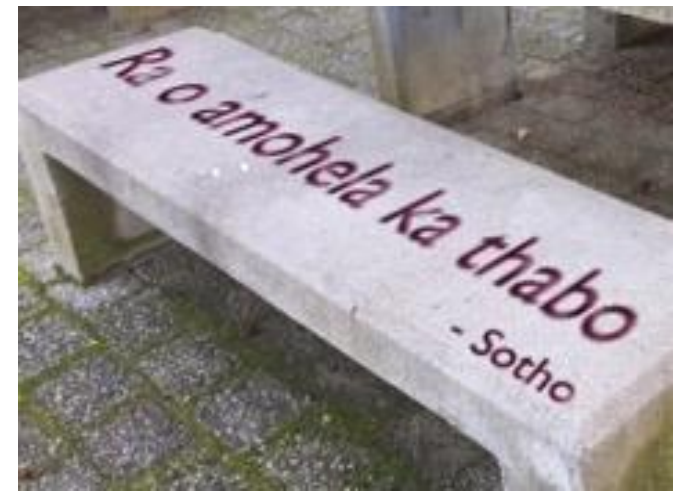

Figure 2: An example of a bench

Even though the Visual Redress project started off by mainly addressing the visual spaces on campus, it soon became clear that the erecting of these sculptures does not, on its own, provide a means to address structural injustices. A relational embodied/material/discursive type of engagement was needed. Workshops were organised to engage in a more embodied manner. Various faculties and one division (the faculties of Law, Theology and Science and the Division for Social Impact) took the initiative in collaboration with the Transformation Office and the Visual

\footnotetext{
${ }^{1}$ Stellenbosch University was one of the former white universities where black, coloured, and Indian students were excluded. The university is partly built on an area that was called Die Vlakte, where coloured residents of Stellenbosch in 1964 were forcefully removed (in terms of the Group Areas Act, No. 41 of 1950) with the aim to segregate the racial groups into separate residential areas. Because of this painful history, redress of these injustices is needed and pertinent at Stellenbosch University.
} 
Arts and Drama departments to create spaces that are more inclusive. These workshops were one of many initiatives that were already taking place in the faculties and the Division for Social Impact. The workshops were conducted with lecturers, students, and community members because we realised that addressing the visual aspects and environment on campus, such as the sculptures, alone is not sufficient. The body and other senses need to be included to confront the injustices and pain of the past and to enable a lasting learning experience for all involved. We therefore introduced the practice of body sculptures where the human body is used to form sculptures so that the experience and learning can be felt in a more embodied way. We specifically referred to the work of Augusto Boal (1979), who developed the practice of image theatre and used body sculptures as an important part of his work and research. Body sculptures are discussed later in the article in more detail in relation to the engagements in the workshops.

Lectures and readings could function in different ways than embodied learning, where the distance between what is read or heard is often too big to relate to or to make a lasting affective impression on the person. The processes that we are following through art practice and performance have the potential to make visible the relations between the embodied, the material and the discursive and in that way could expose social and political hierarchies and power relations. Art and performance in the workshops were used as processes to explore and experiment with issues such as inclusion, transformation, and decolonisation. In this article, the various workshops are discussed, and it is shown how the process and methods used for each workshop emerged through art practices. We argue that working with art processes could become the new means of doing research in education, the humanities, and social sciences.

\section{Art processes}

With the creation of galleries in a modern capitalist system, art was made into an elitist cultural product (Kolbe, et al., 2020). The function of art changed and instead of reaching the larger public, it only serves, through galleries and museums, approximately $2 \%$ of the South African population (Hagg, 2010: 10). Art galleries and museums also only exhibit the final product of the art process. The process of making is not normally shared with the public, even though the process itself is often an interesting part of the artwork. With installation art or more interactive art, the process of making is partly extended to the viewers. The art process itself is also a learning process, where one can experiment and explore ideas freely without a set of regulations. The art process results in creative new ideas because it does not have specific rules to follow. Following the same set of rules will result in producing the same type of knowledge. If there are no specific regulations, there is a better chance of discovering new ways of doing as new combinations of often opposite elements are brought together.

Art processes have always been a practice that included the body and materials. Artists know from experience that matter can be social agents and possess agency. Working with paper as matter (or even text as matter) could bring the artist to new understandings. Text, as printed in a book, can be used as thinking with theory, but also as matter: using the paper on which the text is printed in addition to what its content conveys. The shape of the text, the letter type/font 
itself, how the paper is wrinkled, can influence the flow of thinking and doing, while working with text as theory and matter at the same time. Erin Manning and Brain Massumi refer to 'thought in the act' that create ripple effects where 'one idea becomes a seed for organization, which becomes a proposition for a concept, which becomes a problem for art, for politics, for philosophy, that may, if the conditions are ripe, resolve itself into the triggering of an event of collective experimentation and creative expression' (2014: vii). Art processes allow for experimentation because they are processes where thought and action simultaneously happen and where mistakes or accidents could contribute to new understandings.

In theatre, the audience in the role of passive recipient of what is presented on a demarcated proscenium stage was part of a later development of a professionalised theatre practice moving away from more engaged interactive creative practices (White, 2013). The theatrical forms that developed in the West, also referred to as 'formal' or 'literary theatre', were focused on separation between audience and actors (Fleishman, 1990). Mark Fleishman further argues that this Western form of theatre is well suited to 'serve the interests of a particular controlling group' (1990: 95). It is in reaction to the notion of a controlling group determining the rules of creative engagement and expression that Boal's 'Theatre of the Oppressed' developed in Brazil in the 1970s (Boal, 1979). The work of Boal originated in the Brazilian context and focused on the empowerment of the oppressed to be able to address and break cycles and structures of oppression. Part of the focus of Boal's work was on reclaiming the democratic processes originally embedded in theatrical performance practice. Boal (1979) coined the term 'spectactor' to emphasise agency and participation, thereby moving away from the idea that only some have power to enter the performative space.

Image theatre, where physical images (such as body sculptures) are used as resource for further dramatic and theatrical development, stems from this practice and was further developed in North America and Europe and adjusted to those contexts. Performance in the form of image theatre relies on the non-verbal language of bodies in space to 'explore and express internalized and social oppressions' (Saldaña, 2005: 117). In image theatre, the body is reclaimed as a source of knowledge, learning and power (Johnson, 2017: 71). Adam Perry describes image theatre as a 'unique cultural practice that can be used to facilitate counter-discursive stories that are shaped by participants' invitation to play in the space between aesthetic representation and social reality' (2012: 103). Perry (2012) argues that image theatre could evoke an in-between space that could reinvent meaning and create alternative strategies for social justice and decolonising practice. Roxana Ng (2012) describes these embodied learning processes as an 'epistemological restoration of the body-spirit'. Image theatre is addressed again later in this article in a description of one of the workshops that were facilitated with the Faculty of Theology at SU.

The combination of text, thinking, performing and making has always been part of art processes, but their value in teaching, learning and research in education, the humanities and social sciences has only recently being re-emphasised by the new materialist posthuman perspectives. Tamara Borovica refers to Anna Hickey-Moody (2007), who proposes that working with 'aesthetic sensibilities can become new core to how research in the humanities and social 
sciences is able to effect changes in research landscapes because creativity challenges readymade perceptions' (2019: 3).

Art processes are used to enhance creative problem solving without the need to make it a restrictive methodology. The word 'methodology' indicates that there are rules to be followed, and the same rules should be followed every time, while the art process is exactly against following repetitive rules, as it limits the potential for creativity to flow. There are times when the medium or space that is used sets the limitations for artists, but it is not a repetitive methodology as used in case studies or action research. The art process leaves the space open for new possibilities to emerge by themselves. Ideas become fluid in an art process, as it constantly becomes something else. There are no descriptive rules needed in the art process because the parameters are constantly changing. The fact that there are no written rules as in case studies and action research is also the strength of an art process. Peter O'Connor and Michael Anderson argue that in art-based methods, knowledge cannot and should not be 'reduced into words and numbers alone (2015: 24). The representations through image, sound, movement and colour are equally valid ways of expressing knowledge'. They also argue for multiple art forms to be used, such as visual, musical, or performing arts, to understand the world through different modes (O'Connor and Anderson, 2015). In this article, we describe how each different workshop demanded its own process because of the entanglement of various elements at different times. Different art practices, such as painting, sculpting and performance in the form of body sculpting, were used to enable more embodied learning experiences.

\section{Embodied learning workshops}

In 2019 and at the beginning of 2020, various workshops were facilitated on campus and resulted in different outcomes. Most workshops started with a concept ${ }^{2}$ development process (Costandius, 2019) and very often issues such as inclusion, transformation and decolonisation emerged as some of the most pertinent aspects in which students and lecturers were engaging. Even though these themes were not given to the participants, the topics emerged spontaneously during the workshops. The workshops might have started with topics very related to their own professional field, but they would often end with exploring more interrelated personal or socio-political concepts. Art and performance processes, including body sculpting (tableaux) and elements of image theatre used in the workshops, opened up the space for more diffractive and intra-related (Barad, 2007) thinking, doing and learning. The concept of intra-related, differentiated from 'interrelated' with 'intra' meaning 'from within', assumes that there is responsibility involved in the action. New materialist authors such as Karen Barad (2007) and Rosi Braidotti (2013) put forward the idea that we should understand our place in the world as interrelated networks. And, as our worlds are interrelated with others, human and non-human, we should respect everything or everybody equally because they influence us affectively. The relation between the components

\footnotetext{
${ }^{2}$ For clarity: A topic can be described as an undeveloped thought. A concept is considered as a developed thought, while a theory is a fully developed concept.
} 
is relevant, as they affect one another, and the aim is to rethink these relations so that the basis of how we morally and responsibly think, and act is influenced and adjusted.

Body sculptures as a performance technique were used, where groups of people acted as sculptures or series of sculptures to communicate and represent an idea without using spoken language. The participants of the workshops had to trust one another to be able to collaboratively build the body sculptures. The engagement was not only an interaction where they discussed various issues among themselves, but the physicality of body sculptures also made visible the subtle relations that existed between them that enabled collaboration. David Grant also refers to the 'full communicative function' (2017: 193) of using sculpting and image theatre techniques when they are witnessed by others. During these workshops, the participants communicated their own understandings of issues such as inclusion, transformation and decolonisation through art making and performance.

Many processes were followed, and numerous materials were used in each workshop. The participants in the workshops were lecturers, students and community members and there were between fifteen and thirty-one participants per workshop, with two or three facilitators taking part in the art and performance processes. The groups were always of mixed gender and race. The workshops all took place in the specific faculties or the Division for Social Impact and consisted of between four and six sessions, with each session reflecting on the previous one to establish the appropriate process to use for that session. Every workshop was different and reacted to the specific context - each had its own process. At each workshop, different topics emerged spontaneously. The facilitators and participants learned and grew with each process. Workshops at the three faculties and one university service division are discussed below, highlighting some pertinent aspects that emerged during the workshops.

\section{Faculty of Law workshops}

The workshop at the Faculty of Law started with a concept development process where lecturers chose an issue that they found relevant in their own environment and then came up with new topics to better describe their chosen issue. They linked other aspects with their issues and used drawing or painting to help them form new concepts. Issues such as inclusion/exclusion, outsider/insider and indigenous/coloniser emerged from the process. The experimental process created space for a few accidents to happen by coincidence to form new combinations of words and images. The process can be described as diffractive, as one issue was linked with many other related and unrelated issues, such as socio-politics, a plant, an animal, and the immediate environment, to create new meanings.

One of the main issues that emerged in the first workshop was that some felt like insiders or outsiders, or something between an insider and an outsider. This was taken back to the apartheid years, when some of the black, coloured, and Indian lecturers were not allowed on campus or in the building. To demonstrate these feelings, a lecturer drew a 'kraal' ${ }^{3}$ where some

\footnotetext{
${ }^{3} \mathrm{~A}$ 'kraal' is an area with a protected fence to keep farm animals safe.
} 
were kept inside and others outside. As a result of the insider-outsider discussions, a group of life-size cut-out figures was installed in the building as a surprise to students and staff a month later (Figure 3). The installation of the figures in and outside the building triggered the imagination and the topic of insider-outsider infiltrated the curriculum without forcing it on lecturers to include socio-political issues in their curricula.
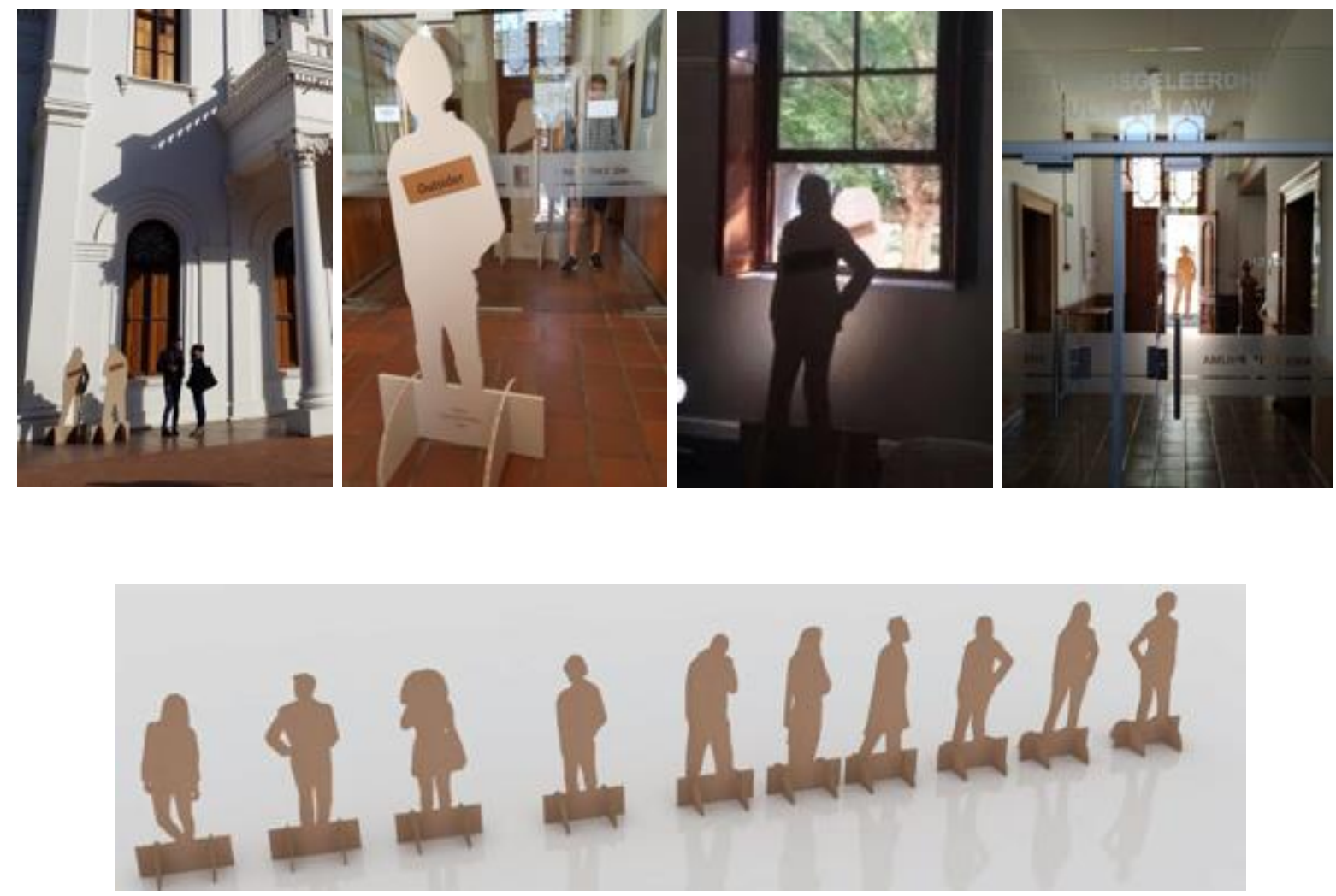

Figure 3: Life-size figures in and outside the Faculty of Law

The photos of lecturers from the apartheid era on the wall in one of the lecture rooms were discussed as examples of where postgraduate law students and law lecturers felt like outsiders who could not associate with the history that the photos represented. This was a time when white people were advantaged and black, coloured, and Indian people disadvantaged, and this was clearly visible in the racial and gender representations of the people in the photos. This installation led to the second workshop, where students were asked to engage with the photos themselves. The concept of Bennett's (2010) 'thing-power' was shared with the students. Bennett argues that thing-power is 'the curious ability of inanimate things to animate, to act, to produce effects dramatic and subtle' (2010: 6). In a new materialist sense, an object has character, is able to speak back to its observers, and the matter that appears is 'a self-disclosing activity' (Massumi, 2002: 228).

With the concept of thing-power in mind, the focus was placed on agency of the performing body. The participants engaged in physical and playful warm-up activities to prepare 
for the performative action of removing the photos from the wall. It was also agreed that the photos would be put back after artistic and performative engagement. The participants were able to work out their own strategy, which in turn assisted in creating the necessary boundaries for safe yet spontaneous and explorative work that opened up the potential to play with new possibilities. This engagement became a performance piece where the photos were removed from the wall and placed in front of the students and they wrote and drew what the photos meant to them, or the power that the photos and the space had on them. Through their initial planned action and within the agreement of the removal of the photographs as performance, students were able to reclaim agency. Gareth White points out that an important aspect of performance is that the participant performer is the one managing his/her presentation, which allows for 'becoming ourselves' (2013: 5). Facilitators and participants observed changes in physicality, as students were able to interact with objects representing perceived power in their environment. Their explorations were then shared with the group.

After a break, the facilitators placed different-coloured material in the space to use with the photos. That was the moment when the students realised that they were now stepping into the space of the photos; the relation between themselves, the photos and the material now became entangled. This process was handled in a very respectful way. Some students wrapped the photos (Figure 4), some closed the eyes of the person on the photo (Figure 5) and another student wrapped a piece of pink material tracing the shape of a man's face (Figure 6). The student did it spontaneously - without thinking about it for a long time. Even though the student did not mean to wrap the face in the shape of a 'hijab', 4 the look of a hijab transpired afterwards.

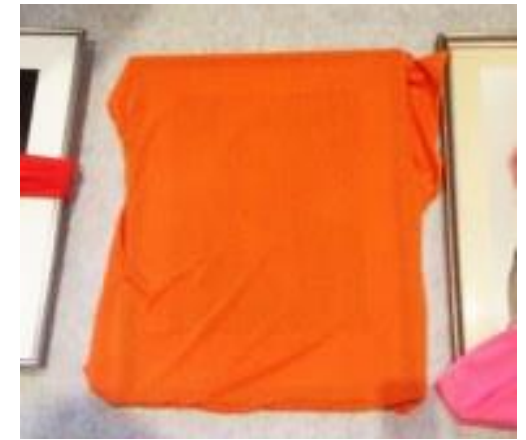

Figure 4: A wrapped photo

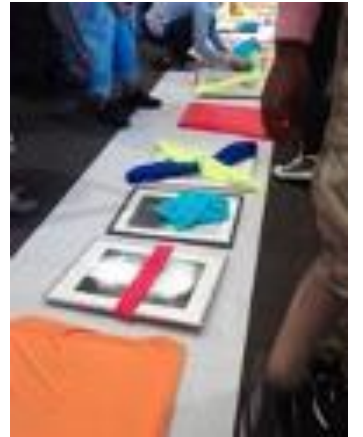

Figure 5: Photo interactions5

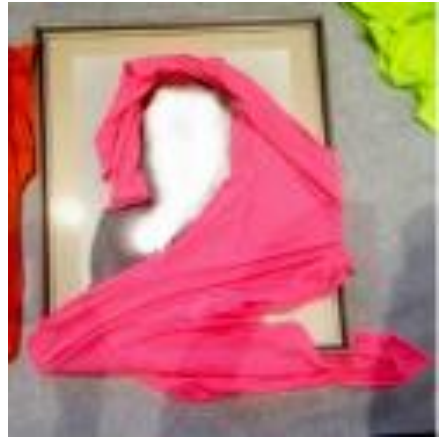

Figure 6: Cloth draped around the face 6

In the reflection sessions after the interaction with the photos, a student commented that the entanglement of the photo, the material and herself resulted in an action that she did not control; the entanglement performed by itself. After reading an article about the power of things

\footnotetext{
${ }^{4} \mathrm{~A}$ hijab is a veil worn by some Muslim women that covers their head and hair.

${ }^{5}$ The face has been blurred to protect the identity of the person.

${ }^{6}$ The face has been blurred to protect the identity of the person.
} 
(Bennett, 2010: 2), someone else would not have drawn the same affective reaction as that spontaneous reaction. Reading often only engages some part of our senses and therefore also affects us only partly. Reading could possibly stay distanced from the mind and does not affect the body as strongly. It is only when the mind and action in context come together that the affect becomes stronger. The social and political conversations about the past and its affect presently, in combination with the material and movement, brought the experience into the student's body - an embodied learning.

The social and political conversations also emerged because of the rhizomatic manner in which the art process in the workshops functioned. The art process opened up the space to link whatever came to mind in a non-hierarchical and non-linear way to multiple connecting points, and very often the socio-political issues that the participants experienced in their lives, especially because of the colonial and apartheid experiences that many people in South Africa had, emerged. The rhizome can be described as a group of multiplicities bound together and in relation to one another that continuously reshape and reform. The process that we followed by indirectly opening spaces through art practice and performance has the potential to make visible the links between spaces, bodies and the discursive and in that way expose the social and political hierarchies and power relations.

When topics emerged spontaneously, the participants were more willing to discuss the issues, as they felt that they had discovered it themselves and it was not a top-down process. The aim of learning is to have a lasting effect, and the imprint that the combination of mind/body/material/space makes could have a better result than only working cognitively. This process relates to what Hickey-Moody, et al. refer to as the 'potential to produce, embody and theorise simultaneously' (2016: 213). From this, simultaneous interactions, or rather intra-action (Barad, 2007), took place and different topics, such as gender relations, religious tolerance and what is sacred in different religions, emerged spontaneously. Barad describes intra-actions as not occurring 'in' determinate space and time, but says each intra-action alters the configurations, which she calls 'spacetimemattering' (2018: 63). Barad argues that 'feeling, desiring and experiencing are not singular characteristics or capacities of human consciousness' (2012: 59). The intra-actions could produce meaning and events in themselves; matter is lively, has agency and is infused with affect (Koro-Ljungberg et al., 2018).

\section{Faculty of Theology workshops}

The first Faculty of Theology workshop started with lecturers and students familiarising themselves with the room in which the workshop was held. It was a room they already knew and often used for lectures, but they had to find objects that they had not seen before. They assembled in groups of five and were then asked to act out and use their bodies to sculpt how they experienced the space; manipulating their bodies to create images together. Each person became a building block for these spontaneous images, which again were recognised to hold complexity of meaning. 
The Theology building (Figure 7) was built on a piece of land that used to be the area where the indigenous Khoi and San people gathered for specific occasions before the arrival of the colonisers and settlers (Giliomee, 2007). Excavations were done and the findings are also exhibited in the building. In the group of participants there were people who had family roots that went back to the Khoi and San as well as people who were descendants from the white settlers. When lecturers and students were made aware of the history, it created a complex and multi-layered space where they felt unsure about their relation to the building and the ground where it was built. The participants were then asked to imagine and build in groups (using their bodies) a new building where more people would feel included. Figures 8 and 9 show the images that some of the groups formed. ${ }^{7}$
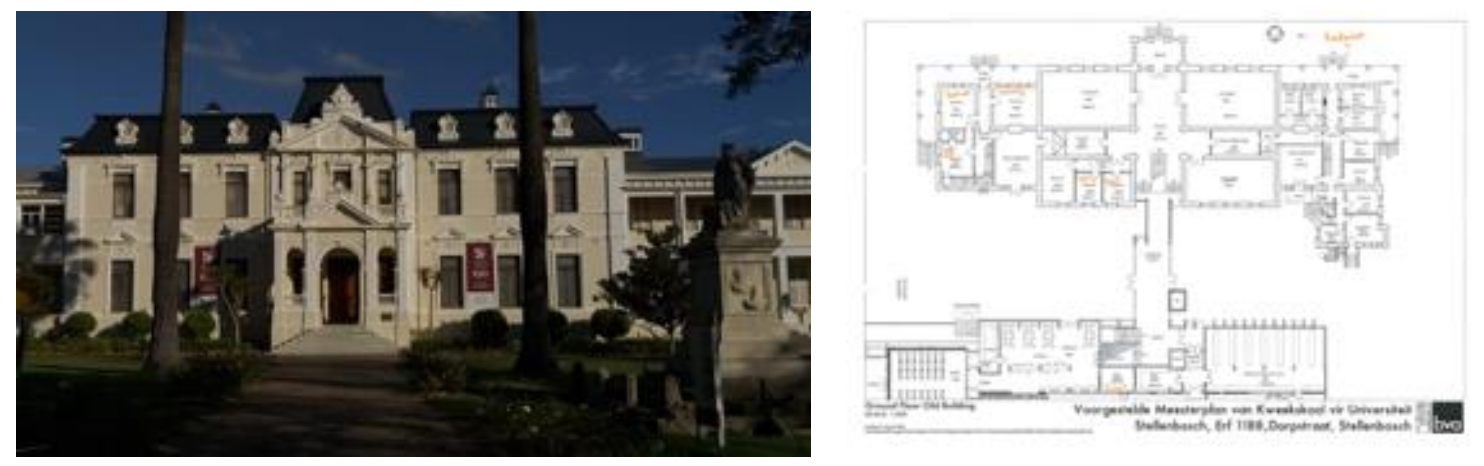

Figure 7: The Theology Building

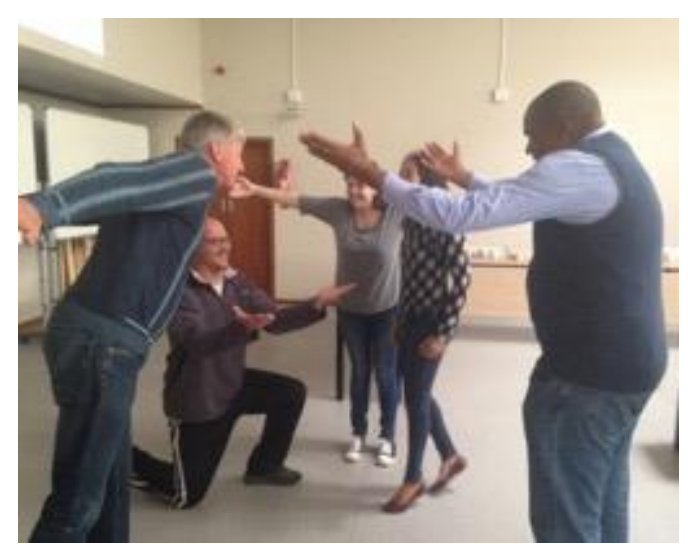

Figure 8: Participants taking part in body sculpture

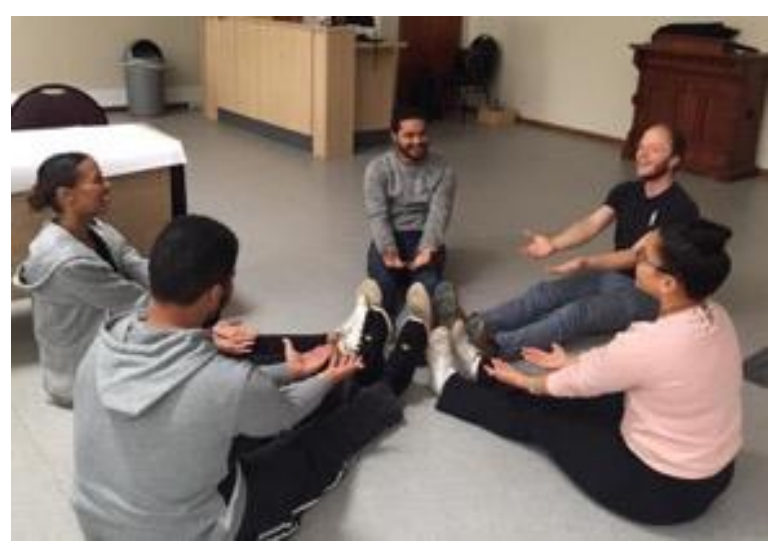

Figure 9: Imagining an inclusive building

Hickey-Moody, et al. describe bodies as 'discursive practices themselves, and they are inseparable from the environments in which they move, shape and express themselves', while

\footnotetext{
${ }^{7}$ Figure 9 is an idea that could be used as a starting point for an architect on which to base his/her design.
} 
the performance image is 'a discursive practice that can be read as we read a text' (as in the case of the Theology building practices) (2016: 216). The history of the building and bodies, matter and meaning became entangled (see Barad, 2007). These bodily performances in the form of image theatre produced knowledge in action. These performances created in the workshop were recorded and the outlines of the figures could be used as a background for photos that are currently on the walls (Figure 10). The outlines of the figures could be read as shadows that told another story apart from what was represented on the walls. The outlines could cut through as if they disrupted the conventional telling of the story. In this process again new topics developed regarding the building, bodies and meaning and were further discussed afterwards by the participants in the reflection session.
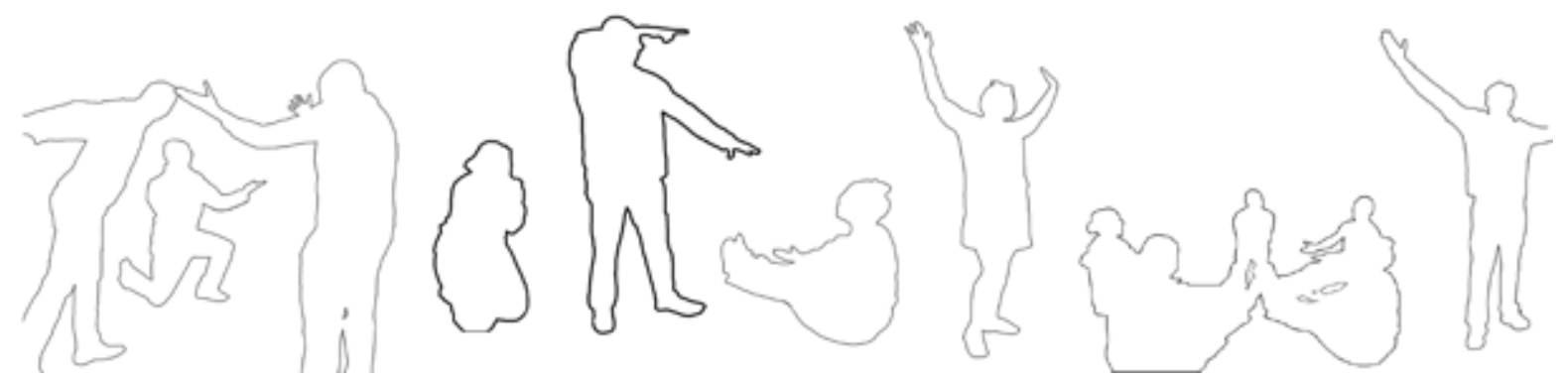

Figure 10: Outlines of the figures

\section{Physiological Science workshops}

These workshops started when some of the lecturers and students at the Department of Physiological Sciences decided that they wanted to change the entrance hall of their building. Originally, they only planned for one workshop, but one workshop led to another. In one of the workshops they worked with natural materials (figures 11 to 13) and concepts of diversity, integration, empathy, embracing, strength together and ubuntu emerged from their interaction with the natural materials. They did not decide on the topics beforehand; they simply started to work and saw where the materials took them. This process allowed the materials to speak, and the people to speak through the materials, and the participants became entangled with the materials and space, as seen in the examples below (figures 11 to 13).

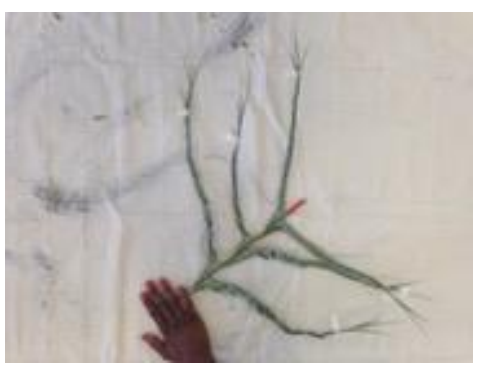

Figure 11: Embracing

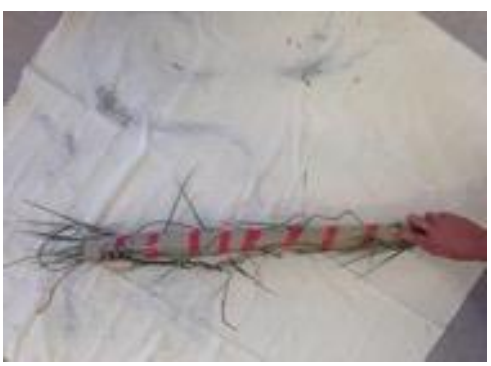

Figure 12: Strength together

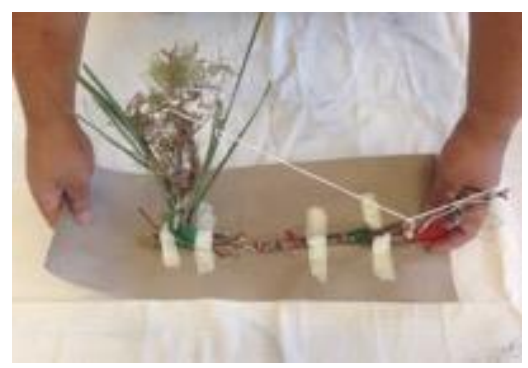

Figure 13: Diversity 
It became apparent that various arts forms/techniques from the visual and performing arts were necessary to evoke, contain and assist to discover during this workshop process. Dynamic movement and interaction between art forms and activities developed. One of the interesting concepts that emerged during one of the body sculpture sessions was when the participants had to build with their bodies the concept words they had chosen. Figures 14 and 15 show the body sculptures of the words 'support' and 'unity'. It was interesting that most of the actions were collaborative, meaning that their bodies were connected in some or other way. Figure 16 depicts the word 'identity' and here the body sculptures were all individual; the bodies separated when they acted the topic 'identity'.

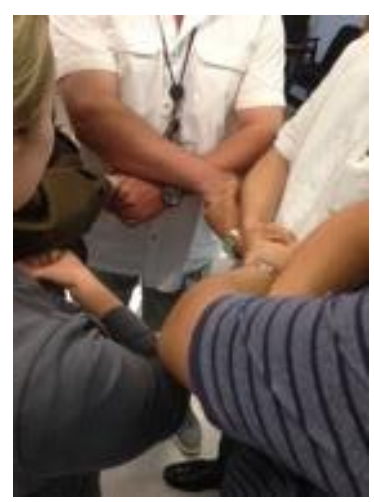

Figure 14: 'Support' body sculpture

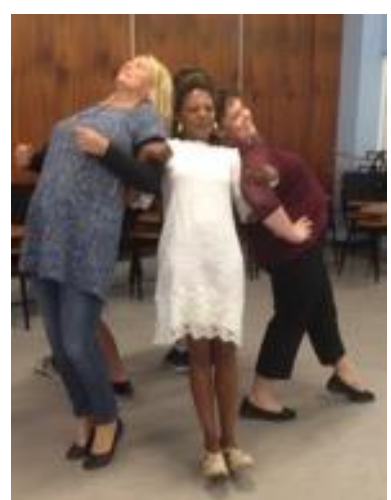

Figure 15: 'Unity' body sculpture

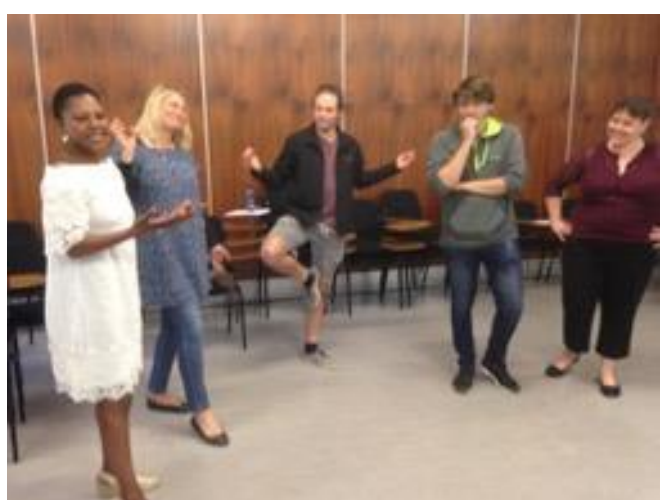

Figure 16: 'Identity' body sculpture

The question was posed as to why the group of bodies decided to spontaneously react in this way. With these image theatre body sculptures, we found that the process sometimes ran away with itself, without participants consciously thinking what happened. It was as if the affective side took over and the thinking mind did not have time to interpret what had happened. It is exactly at this moment that the unrestricted and unedited reactions emerge that are often surprising. This type of learning reaches parts that are normally not accessed because the thinking and actions are constantly edited. An instant body sculpture provokes the body to react spontaneously and act in new ways unknown to the self. Hickey-Moody and Malins argue that artistic practice 'slips between cracks in consciousness, assumption and the "known" through making new bodies and creating accompanying original ways of knowing' (2007: 86). According to Borovica, artistic practices could surprise us with 'new sensations, feelings and thoughts about a phenomenon', and aesthetic methods could 'open up a liminal space for imagining what was previously unimaginable' (2019: 9).

Furthermore, the interplay between activities - art making, reflecting and embodied work - deepened the exploration. The participants responded to artwork with embodied images and vice versa. Verbal or written reflection was invited through one-word offerings. The participants were also able to move words (such as 'support', 'integration', and 'collective') written on separate 
pieces of paper in the workshop space and move their own bodies in relation to the words and concepts. This led to an organic movement in space and various workshop participants grouping together at different stages. In turn, this process offered the opportunity to share various assumptions and perceptions regarding phrases and words related to the process. During reflection on the actions with the students and lecturers afterwards, new insights and learning emerged. There were times when we and the participants felt overwhelmed and uncomfortable, and reflecting on those moments became valuable learning experiences.

\section{The Division for Social Impact / Lückhoff School workshop}

The Lückhoff School is situated in Die Vlakte, an area where, in 1964, 'coloured' people were forcefully removed as part of the apartheid laws under the Group Areas Act of 1950, which enforced separate development. The official history of Die Vlakte has been excluded for many years and only in 2006 with the publishing of In Ons Bloed (Biscombe, 2006) and Nog Altyd Hier Gewees: Die Storie van 'n Stellenbosse Gemeenskap (Giliomee, 2007) was its history made public. The Lückhoff School was one of the schools that was evacuated, and children had to carry their benches for a few kilometres to the new school in Idas Valley. The building currently belongs to $\mathrm{SU}$ and is housed in the Division for Social Impact.

Before the first workshop, the staff of the Division for Social Impact organised a remembrance walk where children of the new school in Idas Valley carried two of the original benches back to the Lückhoff School. This again served as an important performative act acknowledging and emphasising the power and value of objects (Carlson, 1996). The workshop took place in the Lückhoff School and the participants were a small group of community members who were taught at the school. The workshop started with a walk through the building without talking to one another to leave some space to experience it with all the senses. The participants were encouraged to approach it as a walking meditation, each walking through the building and engaging with the environment, rather than with one another. The facilitators asked the participants to use the drawing of the building (figures 17 to 19) and fill in what they remembered of each room of the building. 

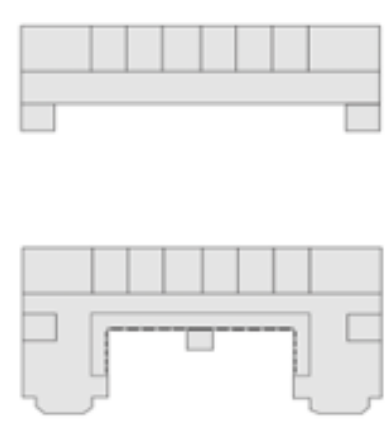

Figure 17: The Lückhoff School floor plan

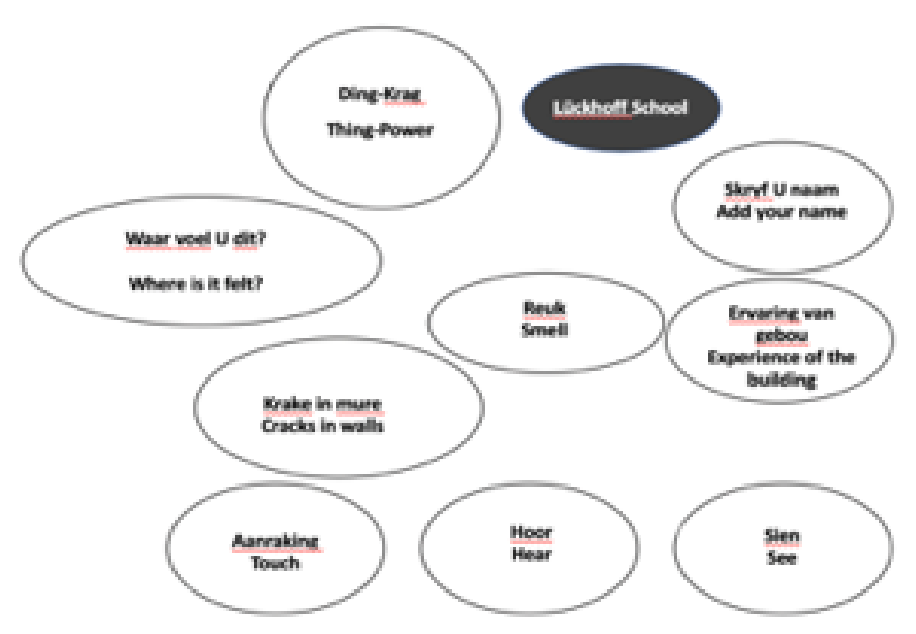

Figure 18: The Lückhoff School workshop process
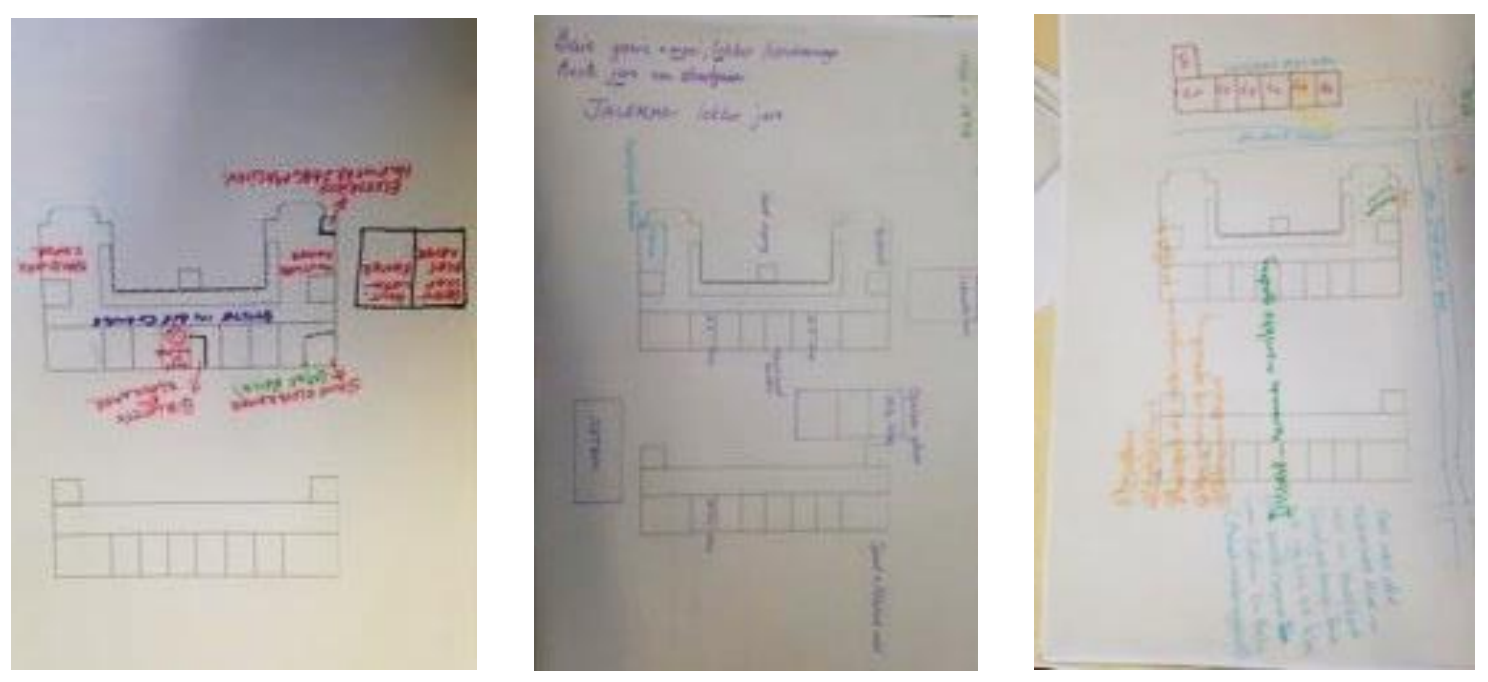

Figure 19: Examples of the participants'work at the Lückhoff School workshop

The participants went through each room and tried to remember the smells (for instance the smell of wood in the woodworking classroom where the workshop took place), what they could see (for instance cracks on the walls), how it felt (for instance the benches on which they sat) or what feeling they experienced when thinking about the past and present in the building after so many years. The engagements in this workshop elicited intense pain, but also moments of joy and laughter. Some participants remembered waiting in the hallway in front of the headmaster's office when they were in trouble. The embodied experiences (drawing, writing and image theatre) in which the participants were engaged recalled many memories that resulted in various affective reactions. The group was able to construct a collective story through artistic engagement, each being able to add a fragment of history that they remembered as part of the 
collective memory. Fragments of stories that did not fit a previously formed master narrative could come to the fore. Through aesthetic engagement of embodied work and art making, participants were able to share, create and find meaning without the pressure of constructing neat narratives or fulfilling expectations of classical art or theatre making (Stalpaert, 2015). Ideas emerged about starting a live museum now that the experiences were made live at the workshop, and the idea of a play that the participants, together with drama students, could perform in the school during the annual Woordfees ${ }^{8}$ festival was discussed. This relates to what Basu and Macdonald suggest: that it is often the coming together of affective agents that offers 'generation rather than reproduction of knowledge and experience' (2007: 2-3).

\section{Discussion}

These workshops were conducted with lecturers, students, and community members because we realised that addressing the visual (the artworks installed on campus) alone is not sufficient. Other senses needed to be included to confront the injustices and pain of the past and to enable a more lasting learning experience for all involved. The lecturers and students who took part did not all feel comfortable with using drawings, paint, clay, or performance to express themselves. There was one person who decided to leave while a workshop was in action. Some immediately replied that they cannot draw or perform, and it was often those who used the medium the best to express themselves. We learned to appreciate how things came together that produce certain relations and how the relations led to new understandings. The lecturers and students were often surprised with what they could spontaneously produce, even though it was not planned beforehand. The coming together of ideas, bodies and material produced knowledge that was unexpected and new. These new knowledges and ways of knowing could include embodied/embrained 'knowing' and new insights and realisations regarding the self in relation to others, specifically related to race, class, gender and sexual orientation. Art processes and performance in combination with thinking and material often trigger some unconscious thoughts to come to consciousness. The mind is often not aware of what the body can and wants to express, in the same way that things get muddled up in dreams, where unusual combinations of, for instance, unconscious/conscious, illogical/logic, humoristic/sad could all appear at the same moment, and could emerge during an entangled mind/body/material art and performance process.

The entangled manner of engaging with these issues has the potential to become alternative methodologies where the experiences of misrecognition, injustice, harm, or shame are not only talked about, but also visualised and performed. Unexpected ideas that unsettle the status quo could result from embodied, material, and discursive engagements because art processes are exploratory, experiential and unpredictable. In new materialist terms, Borovica (2019: 8) regards 'matter (all kinds of matter) not only as something that gets to be formed by

\footnotetext{
${ }^{8}$ The Woordfees festival is one of seven major arts festivals in South Africa. These arts festivals form part of the infrastructure for art practices in the country. Each festival also acknowledges and presents relationships with local communities and identifies with the immediate cultural environment.
} 
the forces of language, culture and politics, but as something that is formative by itself'. It is not only the person who worked with the material who has agency, but matter/materials used in the art process could also have their own agency and can elicit new meanings.

The process of writing (also this article) is also a creative way of letting the subconscious come to the conscious. It is a process that at times flows without effort, and the words come without considering them. Our writing process is similar to what happens when making an artwork or doing an image theatre performance. However, the creative process of the workshops did not end with writing it up in this article; it continued when the participants of the workshops read it and gave their feedback. This feedback has the potential to cut through the parts that our own subjective perspectives overlooked, such as that it is important who writes about visual redress, and that redress should not only be written about, but should also happen when writing or publishing this article. We cannot on our own as white artists receive the benefit of this article and promote our careers by writing about participants and not give them the credit they deserve. We therefore acknowledge the sensitivity of these processes and the important work that all faculties are doing, apart from the workshops, which is a very small part of what materialises on a broader scale at faculties and the Division for Social Impact. The people who made these workshops possible are Profs Bradley Slade, Reggie Nel, Nadine Bowers-Du Toit and Faadiel Essop and Ms Reneé Hector-Kannemeyer. The Visual Redress process is driven by the Transformation Office and the Transformation Committee, and specifically Prof. Nico Koopman and Dr Leslie van Rooi. We consider the feedback from all people involved as a necessary part of the creative process needed for the Visual Redress project to continuously be in a process of becoming.

\section{Conclusion}

In this article various workshops were discussed as well as the way in which various topics and processes at each workshop emerged during the interactions. The processes followed for each faculty and the Division for Social Impact became clear while in action and sometimes in reflection on the actions. Developing specific processes beforehand for all the different situations or contexts - and variants that they contain or entangle with - often hinders spontaneous and creative discoveries. Allowing the space, bodies, and material to interact on an equal basis opens up a space for new processes or methods to emerge. The art and performance actions that the facilitators suggested are only some of the role players in the intra-action, where the space is left open for other role players (space, bodies) to speak for themselves. The workshops, with all the actors involved, revealed the topics that were most prominent in the participants' minds. Some of the topics that emerged came as a surprise, while others confirmed what they already knew or revealed what they knew was important to them. The space, body and material also allowed for some new topics to emerge.

We are not interested in proclaiming that these workshops were successful or not, as it is the continuous collaborative learning from the process that is valuable. It is more important to open up space where questions emerge instead of analysing and answering the questions 
(Mirzoeff, 2017). These intra-actions opened up avenues to experiment instead of finding solutions. We are constantly seeking new processes or methods and meaning-making intraactions, but not with the aim of finding the ideal and final methodology to be followed. It goes against the very essence of an artistic process where there are no regulations regarding what the correct methods or theories are to be used, where space, body and material are free to use what emerges in the thought process at that moment. The issues of decolonisation and decoloniality are already inscribed in the space, bodies, and material that we use; they just need to be allowed to speak for themselves. The processes that we are following through art practice and performance have the potential to make visible the relations between the embodied, the material and the discursive and in that way expose social and political hierarchies and power relations. We argue that working with body, material, and theory simultaneously in the way art processes work should open up new and creative avenues for doing learning, teaching and research. We agree with Hickey-Moody, who maintains that working with art processes can become the new means of doing research in education, the humanities and social sciences, which has the ability to effect changes in the research, teaching and learning landscapes (2013: 85). We are not against formal methodologies such as case studies or action research, but we have learned through the experiences of these workshops that art processes can further enhance learning, teaching, and research practices.

\section{Author Biographies}

Elmarie Costandius is an associate professor in Art Education, coordinates the MA in Visual Arts (Art Education) and supervises PhD students in Art Education at Stellenbosch University, South Africa. Elmarie has published in the field of art education, critical citizenship, decolonisation, and social justice in local and international journals.

Amelda Brand has worked as a theatre practitioner for over 25 years. She graduated with a BDrama in Performance and MDrama in Community Based Theatre at Stellenbosch University, where she is currently lecturer in Applied Theatre. She also holds a Masters in Drama Therapy from Concordia University, Montreal.

Gera de Villiers holds a doctorate in Visual Art (Museology) from Stellenbosch University, South Africa where she is a Postdoctoral Fellow for the Visual Redress Project. Her interest lies in museums and their transformation towards inclusive spaces. She also has an MA in Museum Studies from Georgetown University, Washington D.C.

\section{References}

Barad, K. 2007. Meeting the Universe Halfway: Quantum Physics and the Entanglement of Matter and Meaning. Durham, NC: Duke University Press.

Barad, K. 2012. Interview. In Dolphijn, R. \& Van der Tuin, I. (eds.) New Materialism: Interviews and Cartographies. Ann Arbor, MI: Open Humanities Press, 48-70. 
Barad, K. 2018. Troubling time/s and ecologies of nothingness: Re-turning, re-membering, and facing the incalculable. New Formations: A Journal of Culture/Theory/Politics, 92: 56-86.

Basu, P. \& Macdonald, S. (eds.) 2007. Exhibition Experiments. Malden, MA: Blackwell.

Bennett, J. 2010. Vibrant Matter: A Political Economy of Things. Durham, NC: Duke University Press

Bentley, K. \& Habib, A. 2008. Racial Redress \& Citizenship in South Africa. Cape Town: HSRC Press.

Biscombe, H. 2006. In Ons Bloed. Stellenbosch: Sun Press.

Boal, A. 1979. Theatre of the Oppressed. London: Pluto Press.

Borovica, T. 2019. Dance as a way of knowing: A creative inquiry into the embodiment of womanhood through dance. Leisure Studies, Special Issue: 1-21.

Braidotti, R. 2013. The Posthuman. Cambridge: Polity Press.

Carlson, M.1996. Performance. A Critical Introduction. London \& New York: Routledge.

Costandius, E. 2019. Fostering the conditions for creative concept development. Cogent Education, 6(1): 1-10.

Fleishman, M. 1990. Workshop theatre as oppositional form. South African Theatre Journal, 4(1): 88-118.

Giliomee, H. B. 2007. Nog Altyd Hier Gewees: Die Storie van 'n Stellenbosse Gemeenskap. Cape Town: Tafelberg.

Grant, D. 2017. Feeling for meaning: The making and understanding of Image Theatre. Research in Drama Education, 22(2): 186-201.

Hagg, G. 2010. Assessment of the visual arts in South Africa. South African Government. Available at: http://www.gov.za/documents/research-report-assessment-visual-arts-south-africa (accessed 24 June 2016).

Hickey-Moody, A. 2013. Affect as method: Feelings, aesthetics and affective pedagogy. In Coleman, R. \& Ringrose, J. (eds.) Deleuze and Research Methodologies. Edinburgh: Edinburgh University Press, 79-95.

Hickey-Moody, A. \& Malins, P. 2007. Deleuzian Encounters: Studies in Contemporary Social Issues. New York, NY: Palgrave Macmillan.

Hickey-Moody, A., Palmer, H. \& Sayers, E. 2016. Diffractive pedagogies: Dancing across new materialist imaginaries. Gender and Education, 28(2): 213-229.

Johnson, R. 2017. Embodied Social Justice. London: Routledge.

Kolbe, K., Upton-Hansen, C., Savage, M., Lacey, N. \& Cant, S. 2020. The Art World's Response to the Challenge of Inequality. Working Paper No. 40. London: International Inequalities Institute, London School of Economics and Political Science.

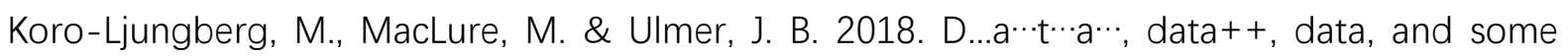
problematics. In Denzin, N. K. \& Lincoln, Y. S. (eds.) The Sage Handbook of Qualitative Research. 5th Edition. Los Angeles, CA: Sage, 462-484.

Le Grange, L. 2018. Decolonising, Africanising, indigenising and internationalising of curriculum studies: Opportunities to (re)imagine the field. Journal of Education, 74: 5-18. 
Manning, E. \& Massumi, B. 2014. Thought in the Act: Passages in the Ecology of Experience. Minneapolis, MN: University of Minnesota Press.

Massumi, B. 2002. Parables for the Virtual: Movement, Affect, Sensation. Durham, NC: Duke University Press.

Mirzoeff, 2017. D. Decolonising media. Available at: http://nicholasmirzoeff.com/decolonizingmedia/ (accessed 25 October 2019).

$\mathrm{Ng}$, R. 2012. Decolonising teaching and learning through embodied learning: Toward an integrated approach. In Edmonton, R. F. (ed.) Valences of Interdisciplinarity. Edmonton: Athabasca University Press, 343-365.

O'Connor, P. \& Anderson, M. 2015. Applied Theatre. Research. Radical Departures. London: Bloomsbury.

Perry, J. R. 2012. A silent revolution: 'Image theatre' as a system of decolonisation. Research in Drama Education: The Journal of Applied Theatre and Performance, 17(1): 103-119.

Saldaña, J. 2005. Theatre of the Oppressed with children: A field experiment. Youth Theatre Journal, 19(1): 117-133.

Stalpaert, C. 2015. Towards an embodied poetics of failure: Some sideway glances on violence and trauma in Needcompany's Marketplace 76. Performance Research: A Journal of the Performing Arts, 20(1): 56-71.

White, G. 2013. Audience Participation in Theatre: Aesthetics of the Invitation. New York, NY: Palgrave Macmillan. 